\title{
Production and Some Properties of the Intracellular Protease of Leuconostoc citrovorum*
}

\author{
Fumisaburo Tokita and Akiyoshi Hosono \\ Faculty of Agriculture, Shinshu University, Ina-shi, 396 \\ (Received November 17, 1975)
}

\begin{abstract}
The present study was undertaken to provide some basic aspects of the intracellular protease of Leuconostoc citrovorum IAM 1087. Leu. citrovorum producted intracellular protease optimally at $30 \mathrm{C}$ and production of intracellular protease reached a maximum in $24 \mathrm{hr}$. The optimum $\mathrm{pH}$ of the intracellular protease which was prepared from the cells grown at $30 \mathrm{C}$ for $24 \mathrm{hr}$ by sonication and ammonium sulfate precipitation was 7.5 in phosphate buffer. The optimum temperature was $45 \mathrm{C}$, and the inactivation of the protease was observed to begin already even at $40 \mathrm{C}$. The protease hydrolyzed more actively $\alpha_{8}$-casein than the other casein fractions.
\end{abstract}

Production of proteases by homofermentative lactic acid bacteria is well known. These proteases usually play an important role in the ripening of various types of cheeses. With the purpose to investigate biochemical changes occurring during cheese making and ripening, production and properties of intracellular ${ }^{1-4)}$ or extracellular ${ }^{5,6)}$ proteases from lactic streptococci and lactobacilli have been studied by many workers ${ }^{2-4,7-9)}$. Recently, OHмIYA and SAT0 $0^{70-12)}$ have also carried out extensive studies on the proteolytic actions of dairy lactic acid bacteria such as Streptococcus lactis, S. cremoris and Lactobacillus bulgaricus.

On the other hand, proteolytic actions of heterofermentative lactic acid bacteria which are commonly used as starter cultures for the production of dairy products have been studied by the limited number of investigators. DutTA et al. ${ }^{191}$ examined proteolytic properties of Leuconostoc citrovorum and Leu. dextranicum and recognized that only Leu. citrovorum exhibited appreciable proteolytic activity after 24 and $72 \mathrm{hrs}$ ' incubation in milk.

However, we have as yet little information as to intracellular proteases produced by heterofermentative lactic acid bacteria.

The present study was initiated to investigate the production of intracellular protease by Leu. citrovorum under various cultural conditions and some enzymatic properties of the intracellular protease produced were studied.

\section{Materials and Methods}

Culture: Leu. citrovorum IAM 1087 obtained from the stock culture collection in the Institute of Applied Microbiology, University of Tokyo, was used in this study.

Growth and harvesting of cells: The medium used in this study was composed of lactose $1 \%$, peptone $0.7 \%$, yeast extract $0.5 \%, \mathrm{Na}_{2} \mathrm{HPO}_{4} 0.6 \%$ and $\mathrm{NaH}_{2} \mathrm{PO}_{4} 0.4 \%$ (pH 6.5). Leu. cilrovorum was incubated at $30 \mathrm{C}$ and transferred daily into the above medium. One liter of the medium was dispensed in $200 \mathrm{~m} l$ quantities in $500 \mathrm{~m} l$ flasks. After sterilization each was inoculated with

*Studies on the intracellular protease produced by Leuconostoc citrovorum. I.

Jap. J. Zootech. Sci., 47, (5): 277-282.

1976. 5. 
$1 \mathrm{ml}$ of $24 \mathrm{hrs}$ ' culture and incubated at $30 \mathrm{C}$ for given hours. At the end of incubation, the cells were harvested in a centrifuge operated at $3000 \mathrm{rpm}$ for $20 \mathrm{~min}$. The packed cells were suspended, washed in normal saline $(0.9 \% \mathrm{NaCl})$ and centrifuged two or more times until a clean supernatant fluid was obtained.

Separation of the intracellular protease from the cells: The packed cells were stored at $4 \mathrm{C}$ in $2 \mathrm{gram}$ (wet weight) portions suspended in $20 \mathrm{~m} l$ of sterile deionized water. Twenty milliliters of the cell suspension was placed in a $50 \mathrm{~m} l$ beaker and was put in a mixture of ethanol, sodium chloride and ice sufficient to maintain the temperature below $-10 \mathrm{C}$. The sonifer (Model-TA 4201, Kaijo Denki Co. Ltd., Tokyo) was operated at $40 \mathrm{kHz}$ for $15 \mathrm{~min}$. The unbroken cells and cellular debris were sedimented in a centrifuge at $3000 \mathrm{rpm}$ for $20 \mathrm{~min}$. The supernatant was made up to a volume of $30 \mathrm{~m} l$ by adding sterilized deionized water. To $25 \mathrm{~m} l$ of the enzyme extract adjusted to $\mathrm{pH} 7.0$ was slowly added $38 \mathrm{~m} l$ of saturated ammonium sulfate solution. The resulting precipitate was collected by centrifugation and the intracellular protease was extracted with a minimum amount of $0.1 \mathrm{~m}$ calcium acetate solution. The extract was dialized against tap water for $20 \mathrm{hr}$. After dialysis, the dialized solution was messed up to $20 \mathrm{~m} l$ in whole with $0.1 \mathrm{M}$ phosphate buffer $(\mathrm{pH} \mathrm{7.0)}$ and used as intracellular protease solution.

Preparation of the substrate: Whole casein was prepared from raw fresh skim milk according to the general method of acid casein preraration. $\alpha_{s^{-}}$, crude $\kappa$ - and $\beta$-caseins were prepared by the methods of HIPP et al. ${ }^{14)}$ and WaUgh et al. ${ }^{151}$

A $2 \%$ solution of each casein, which was prepared and adjusted to $\mathrm{pH} 7.0$ was used as substrate. One milliliter of the enzyme solution and $1 \mathrm{~m} l$ of $0.1 \mathrm{M}$ phosphate buffer $(\mathrm{pH} 7.0)$ were added to $1 \mathrm{~m} l$ of the substrate. The digestion mixture was incubated at $30 \mathrm{C}$ for $3 \mathrm{hr}$. After incubation $3 \mathrm{~m} l$ of $5 \%$ trichloroacetic acid (TCA) was added. The mixture, after standing for 30 minutes, was filtered. Absorbance at $280 \mathrm{~nm}$ of the filtrate was measured and the amount of tyrosine was determined by the Lowry et al. modification ${ }^{16}$ of the Folin-CIOCalteau method ${ }^{17)}$. The color developed with the Folin-Ciocalteau reagent was meaured spectrophotometrically at $660 \mathrm{~nm}$. The activity of the enzyme was measured in terms of the difference of optical density (O.D.) at 0 and $3 \mathrm{hr}$. During this period, increase in O.D. showed linear relation with time. Under these conditions of assay, an increase of $0.1 \mathrm{O}$. D. after $3 \mathrm{hr}$ was defined as 1 unit of activity.

Blanks, wherein TCA was added to the enzyme extract before the addition of the substrate were run with all tests.

\section{Results}

Production of intracellular protease:

Production of intracellular protease by Leu. citrovorum is shown in Fig. 1. Enzyme production rapidly increased in the logarithmic phase of growth and reached the maximum at $24 \mathrm{hr}$ of incubation, then gradually decreased.

Fig. 2 shows the relation between temperature of incubation and production of intracellular protease. Production of the intracellular protease by this strain was greatly affected by temperature of incubation, and the optimum termperature was $30 \mathrm{C}$.

Enzymological properties of the intracellular protease:

The intracellular protease which was prepared from the culture incubated for $24 \mathrm{hr}$ at $30 \mathrm{C}$ was used for this experiment. 


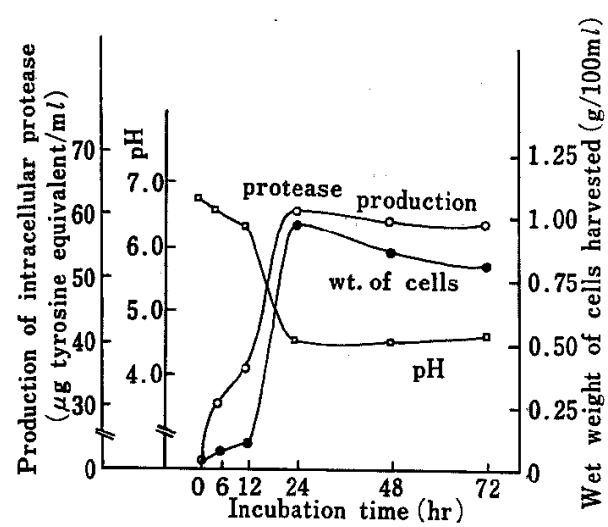

Fig. 1. Production of intracellular protease by Leu. citrovorum.

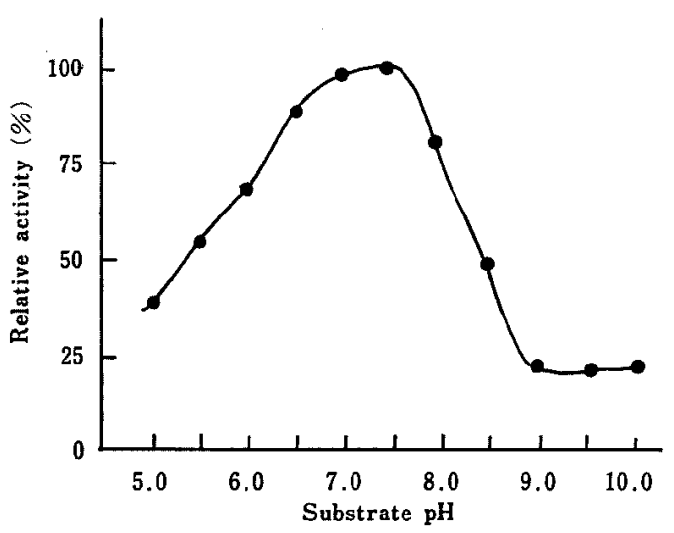

Fig. 3. Effect of $\mathrm{pH}$ on the activity of the intracellular protease.

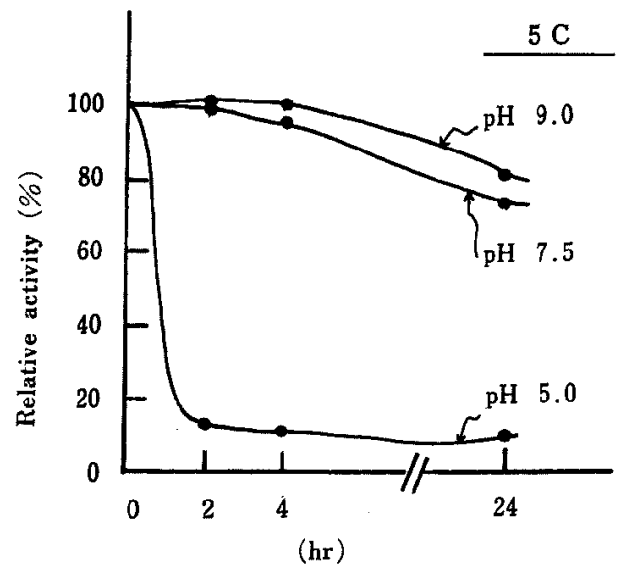

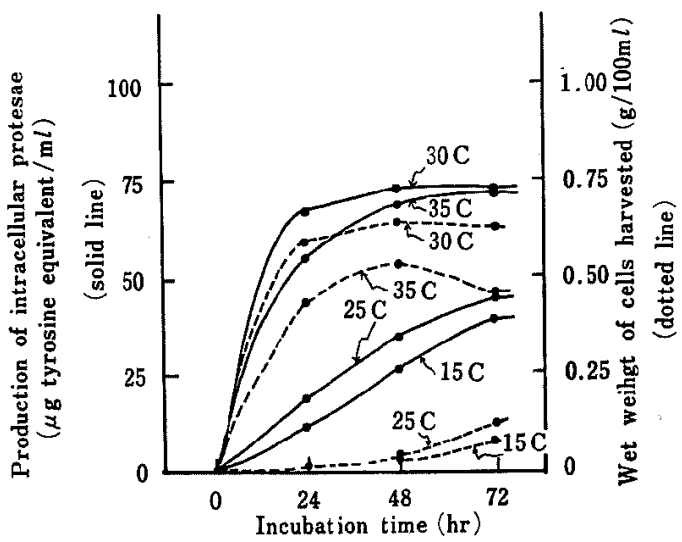

Fig. 2. Effect of incubation temperature on the production of intracellular protease by Leu. citrovorum.

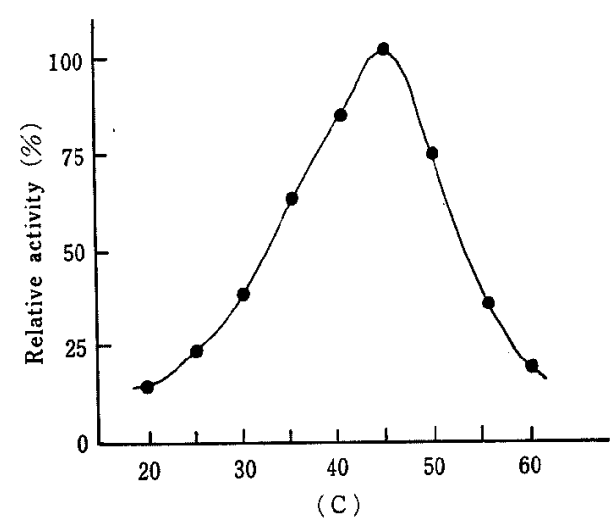

Fig. 4. Effect of temperarure on the activity of the intracellular protease.

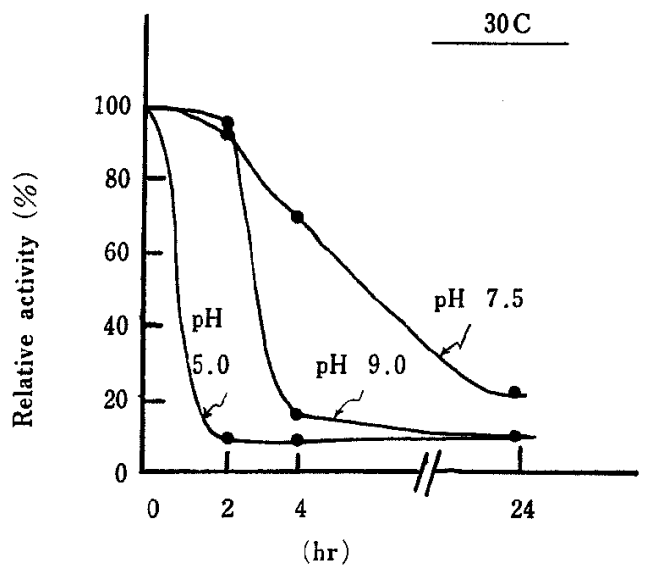

Fig. 5. Effect of temperature and $\mathrm{pH}$ on the stability of the protease activity. 
The optimum $\mathrm{pH}$ of the activity of the intracellular protease was determined with McIlvarne's and Atkins-Pantin's buffer solutions of which $\mathrm{pH}$ levels ranged from 5, 0 to 10.0.

As shown in Fig. 3, it was observed that the enzyme has its optimum activity in the neutral $\mathrm{pH}$ range from $\mathrm{pH} 7.0$ to 7.5 .

The activity of the enzyme preparation at various temperatures from $20 \mathrm{C}$ to $45 \mathrm{C}$ was determined under the standard assay conditions except for the reaction temperature. As Fig. 4 shows, the enzyme preparation was found to have an optimal temperature of $45 \mathrm{C}$, and its activity fell off rapidly above $45 \mathrm{C}$.

Fig. 5 shows stability of the enzyme at various $\mathrm{pH}$. The enzyme preparation of this strain was mixed with $0.1 \mathrm{M}$ phosphate buffer with $\mathrm{pH}$ levels ranging from $\mathrm{pH} 5.0$ to 9.0 and the solution was incubated at either $5 \mathrm{C}$ or $30 \mathrm{C}$ for $24 \mathrm{hr}$. After the incubation, the residual enzyme activities were compared to the initial activity. As can be seen from this figure, the enzyme preparation was found to be most stable at $\mathrm{pH} 9.0$ when incubated at $5 \mathrm{C}$.

The thermal stability of the intracellular protease was measured. Samples of enzyme solutions were stood for $10 \mathrm{~min}$ at $30,35,40,45,50,55$ or $60 \mathrm{C}$ in $0.1 \mathrm{M}$ phosphate buffer $(\mathrm{pH} \mathrm{7.0)}$, and the activities remaining after the incubation were expressed as percentages of the initial activity. As shown in Fig. 6, the protease was found to be remarkably sensitive to heat, i. e., inactivation began already at $40 \mathrm{C}$, and 10 minutes heating at $60 \mathrm{C}$ caused $80 \%$ loss of the original activity.

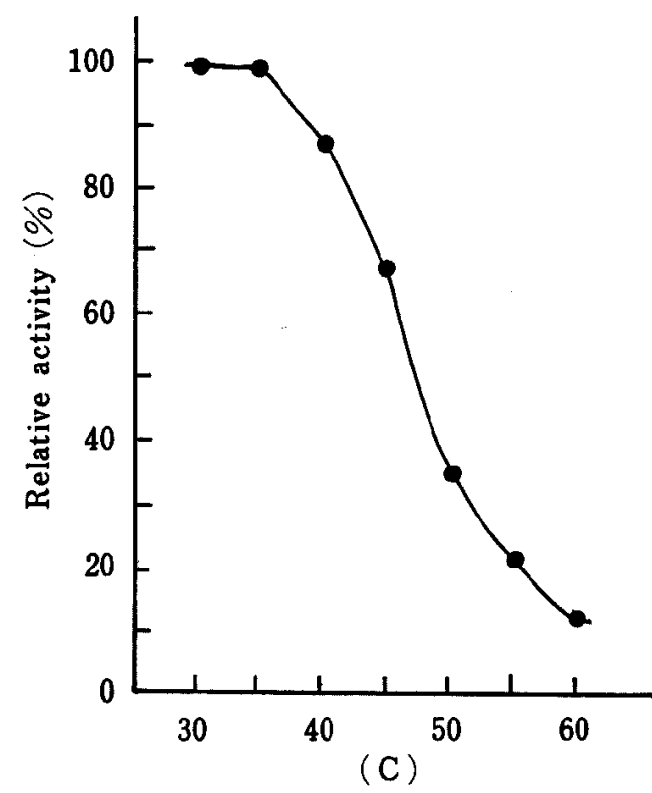

Fig. 6. Thermostability of the intracellular protease.

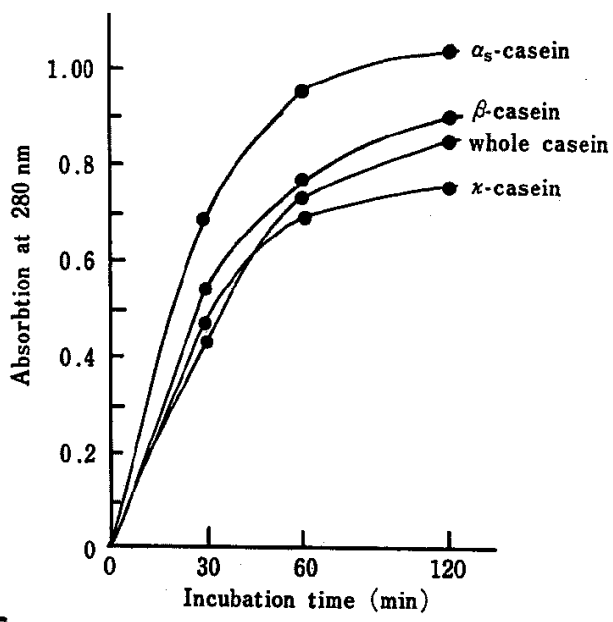

Fig. 7. Proteolysis of casein fractions by the intracellular protease of Leu. citrovorum.

To determine the substrate specificity of the intracellular protease, the abilities of the intracellular protease to hydrolyze various caseins were examined. As shown in Fig. 7, it is noted that $\alpha_{\mathrm{s}}$-casein was more easily hydrolyzed than $\beta-$, whole- and crude $\kappa$-caseins. Hydrolysis of crude $\kappa$-casein seemed to proceed during initial $1 \mathrm{hr}$ but the hydrolysis was not so significant. 


\section{Discussion}

The present study was undertaken to provide some basic aspects of the intracellular protease of Leu. citrovorum which is one of the most representative heterofermentative dairy lactic acid bacteria. Proteolytic enzymes of homofermentative lactic streptococci and lactobacilli are generally known to exist in the cells, $\mathrm{s}^{8-20)}$ with a few exceptions $\mathbf{s}^{5,9}$.

In the preliminary experiment of the present study we recogized that proteolytic activity was mainly found in the cells, and neither culture supernatants nor buffers used to wash intact cells exhibited detectable protease activity. However, no attempt was made to concentrate any protein in the culture fluid, so that the possibility of presence of an extracellular pratease has not been excluded.

FosTeR et al.211 described that Leuconostoc citrovorum strains grow best at $25 \mathrm{C}$ to $30 \mathrm{C}$ and are unable to ferment lactose to any degree. It was observed that Leu. citrovorum used in this experiment grew best at $30 \mathrm{C}$ but very slowly at $25 \mathrm{C}$, and that $\mathrm{pH}$ of the media did not fall down below 4.7 throughout incubation period (Fig. 1).

Optimum $\mathrm{pH}$ of intracellular protease of Leu. citrovorum is in slightly alkaline range compared to those of homofermentative lactic acid bacteria, namely $\mathrm{pH}$ of intracellular proteases of $L$. casei and $S$. cremoris is 6.0 to 7.0 and that intracellular proteases of $L$, bulgaricus and S. lactis have their optima $\mathrm{pH}$ at 7.0 and 6.0 , respectively ${ }^{8)}$.

As shown in Fig. 1 the protease production was not generally occurred after $24 \mathrm{hr}$, when the culture was in the stationary or death phase. We tentatively investigated the properties of the intracellular proteases produced after $24 \mathrm{hr}$ of growth and after $12 \mathrm{hr}$ of growth, when the culture was in the early logarithmic growth phase. However, definite differences were not observed between these protease preparations.

The present observation that $\alpha_{\mathrm{s}}$-casein was more easily hydrolyzed by the intracellular protease of Leu. citrovorum than the other casein fractions is consistent to the results of Oнмгу et al. ${ }^{10,11)}$, who used the intracellular proteases from several strains of homofermentative lactic acid bacteria such as $L$. bulgaricus, L. helveticus, S. latcis and S. cremoris. This fact suggests that substrate specificity of the intracellular protease of Leu. citrovorum has a strong resemblance to those of the intracellular proteases of such homofermentative dairy lactic acid bacteria. For the purpose to gain more detail knowledge of this point, further investigation on the enzymological properties of the intracellular protease of Leu. citrovorum is needed.

Detail investigation on inhibitor and activator requirments of the intracellular protease of Leu. citrovorum will be described in a subsequent report.

The authors express their gratitude to the Institute of Applied Microbilogy, University of Tokyo for supplying lactic acid bacteria.

This work is supported in part by a grant-in-aid for Scientific Research from the Ministry of Education.

\section{References}

1) Miller, I., and O. Kandier, Milchwiss 22: 150-159. 1967.

2) Sashital, K. S., and L. N. Zimmerman, Can J Microbiol 14: 1265-1269, 1968. 
3) Wallace, D. L., and L. G. Horman, J Dairy Sci 53: 394-402. 1970.

4) Westhoff, D. C., and R. A. Cowman, J Dairy Sci 53 : 1286-1287. 1970.

5) SASAKI, R., and T, NAKAE, Jap J Zootech Sci 30: 7-10. 1959.

6) Thomas, T. D., B. D. W. Jarvis, and N. A. Skipper, J Bact 118: 329-333. 1974.

7) OhmiYa, K., and Y. Sato, Agri Biol Chem 32: 291-296. 1968.

8) Sato. Y., and I. NaKajima, J Agri Chem Soc Jap 39: 229-306. 1965.

9) Williamson, W. T., S. B. Tove, and M. L. Speck, J Bact 87: 49-59. 1964.

10) Онмтуа, K., and Y. Sato, Agri Biol Chem 33: 662-668. 1969.

11) Онмгун, K., and Y. Sato, Agri Biol Chem 33: 669-675. 1969.

12) Oнmiya, K., and Y. Sato, Agri Biol Chem 34: 1463-1469. 1970.

13) Dutta, S. M., P. K. Kulla, B. Ranganathan, and H. Laxminarayana, Indian J Dairy Sci 24: 107-114. 1971.

14) Hipp, N. J., M. L. Groves, J. H. Custer, and T. L. McMeexin, J Dairy Sci 35: 272-281. 1952.

15) Waugh, F. D., and H. P. von Hippel, J Am Chem Soc 78: 4576-4582, 1956.

16) Lowry, O. H., N. J. Rosebrough, A. L. Farr, and R. J. Randall, J Biol Chem 193: 265275. 1951.

17) Folin, O., and V. Ciocalteu, J Biol Chem 73: 627-650. 1927.

18) Brandsaeter, E. B., and F. E. Nelron, J Bact 72: 68-72. 1956.

19) Brandsaeter, E. B., and F. E. Nelson, J Bact 72: 73-78. 1956.

20) Zant, W. C. van der, and F. E. Nelson, J Dairy Sci 36: 1212-1222. 1953.

21) Foster, E. M., F.E. Nelson, M. L. Speck, R. N. Doetch, and J.C. Olson, Dairy Microbiology p. 17 Prentice-Hall Inc. 1957.

\title{
Leuconostoc citrovorum による菌体内プロテアーゼの 生産とその性質
}

\author{
铇 田文三郎・細 野 明 義
}

信州大学農学部, 伊那市 396

\begin{abstract}
ホモ型発䤃乳酸菌による菌体内プロテフーゼの生産な らびにその性質については既に詳細な研究がなされてい るが、へテロ型発醉乳酸菌についてはそのプロテフーゼ 活性が微弱であるここもあってほとえど詳しい研究がな されていない，筆者らはへテロ型発酵乳酸菌のうち，乳 製品製造上重要な Leuconostoc citrovorum の菌体内プロ テアーゼの生産と，産生酳素の抽出およびその性質につ いて検討した. $30^{\circ} \mathrm{C}$ で培養開始後，増殖が 対数期に入 った時点で菌体内プロテフーゼが最も顕著に生産され，
\end{abstract}

培養 24 時間目で最高に達し，以後培養時間の経過とと

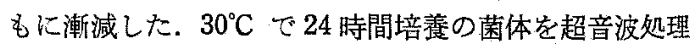
後，硫女分画をして得た酵素液の性質を全カゼインを基 質にして調べた。 その結果，活性至適 $\mathrm{pH}$ 和よび温度が それぞれ 7.5 付近および $45^{\circ} \mathrm{C}$ にあり， $40^{\circ} \mathrm{C}$ で 10 分の 加熱により活性の低下が始まること証めた。 また， $\alpha_{\mathrm{s}}$ カカゼイン, $\beta$-カゼイン, 粗 $\kappa$-カがインのう方, 本酝 素は $\alpha_{\mathrm{s}}$-カゼインを最を顕著に分解することを認めた。 